\title{
Involvement of steroid hormone and growth factor cross-talk in endocrine response in breast cancer
}

\author{
R I Nicholson, R A McClelland, J F R Robertson ${ }^{1}$ and J M W Gee \\ Tenovus Cancer Research Centre, University of Wales College of Medicine, Cardiff CF4 4XX, UK \\ ${ }^{1}$ Department of Surgery, City Hospital, Nottingham NG5 1PB, UK \\ (Requests for offprints should be addressed to R I Nicholson)
}

\begin{abstract}
Multiple lines of evidence implicate steroid hormone and growth factor cross-talk as a modulator of endocrine response in breast cancer and that aberrations in growth factor signaling pathways are a common element in the endocrine resistant phenotype. Delineation of these relationships is thus an important diagnostic goal in cancer research, while the targeting of aberrant growth factor signaling holds the promise of improving therapeutic response rates.
\end{abstract}

Endocrine-Related Cancer (1999) 6 373-387

\section{Introduction}

Research examining those factors affecting the development of breast cancer has identified that steroid hormones are of pivotal importance in directing the growth of these tumours. This knowledge has been exploited clinically, with endocrine treatments which seek to perturb the steroid hormone environment of the tumour cells often promoting extensive remissions in established tumours and, furthermore, significant survival benefits for patients. Unfortunately, the beneficial actions of existing endocrine measures are, in part, counteracted by the capacity of the tumour cells to eventually circumvent the need for steroid hormones, allowing them to continue to grow and progress despite such therapy. Thus, at presentation of breast cancer, current endocrine therapies are not effective in all patients (de novo endocrine resistance) and initially responsive tumours will sooner or later progress despite such treatments (acquired resistance), inevitably resulting in patient relapse and ultimately death. The identification of the factors and pathways responsible for the development of these resistant conditions is therefore an important diagnostic and therapeutic goal in cancer research. It is self-evident that any accurate identification of primary endocrine resistance in advance of therapy would not only prevent unnecessary treatment morbidity in unresponsive patients, but would also significantly limit the time lost during which the disease may progress unchecked by inappropriate therapy, and the waste of financial resources associated with the ever escalating cost of drugs. Equally, a knowledge of the causes of primary and acquired endocrine resistance might allow the development of new therapeutic regimes to either prevent the evolution of these conditions, or at least delay their appearance, hence severely compromising the disease process.

A proposed model for such loss of steroid hormone sensitivity in breast cancer in both the de novo and acquired setting suggests that aberrations advantageous to tumour cell growth occur specifically within key growth factor signalling pathways, allowing mitogenesis to proceed highly efficiently despite the challenge of endocrine therapy. These events may totally circumvent the constraints of classical steroid hormone dependency. However, since growth factor and steroid hormone mitogenic pathways are intimately entwined, any associated phenotypic changes may also serve to exaggerate the actions of steroid hormone signalling pathways and hence enhance the agonistic qualities known to be a feature of many current antihormonal therapies. A new paradigm is thus emerging where knowledge of the expression of growth factor signalling elements may be prognostically relevant in identifying endocrine responsiveness and where appropriate anti-growth factor signalling therapeutic regimes, in combination with antihormonal measures, are thus expected to be beneficial to breast cancer patients.

In light of the above model, the present article briefly outlines the elaborate molecular biology of steroid hormone and growth factor signalling pathway interactions believed to play a central role in normal and 
neoplastic breast mitogenesis. It subsequently examines how changes often occurrent in the breast cancer phenotype could severely perturb the balance of such signalling, and thus providing a possible explanatory hypothesis for the tumour growth associated with the phenomena of de novo and acquired endocrine resistance. A limited discussion of how such data might be thera-peutically exploitable in breast cancer is also included.

\section{Oestrogen receptor (ER) signalling}

Multiple lines of evidence have been established that the steroid hormone oestrogen is an essential factor not only for the normal breast (Clarke et al. 1997), but also for the growth and development of breast cancer (Howell et al. 1997). The effects of oestrogens are mediated primarily through interaction with the ER, which in the absence of steroid ligand resides in a large molecular complex with multiple heat-shock proteins (Segnitz \& Gehring 1995). Importantly, the receptor becomes hyperphosphorylated at several serine and tyrosine residues upon oestrogen binding (Kuiper \& Brinkmann 1994), and specific conformational changes are subsequently induced in the receptor which result in dissociation of heat-shock proteins, receptor dimerisation and nuclear localisation. This favours receptor association with (i) simple oestrogen response elements (EREs) within promoters of target genes (reviewed in White \& Parker 1998) and (ii) composite response elements which bind receptors in addition to other transcription factors (Diamond et al. 1990). Functional analysis of ER has shown it to be a modular protein (Kumar et al. 1987), with two transcriptional activator functions (AF), AF-1 and AF-2 (Kraus et al. 1995). One of the effects of ligand binding is to juxtapose the AF-1 and AF-2 domains through receptor conformational change, thereby generating a productive

Table 1 Growth factor signalling elements which influence ER signalling

\section{Peptide growth factors and receptor tyrosine kinases}

Peptide growth factors bind to plasma membrane-located receptors which possess intracellular tyrosine kinase domains. On ligand binding, receptor dimerisation ensues, allowing each member of the receptor pair to trans-phosphorylate its partner specifically on tyrosine residues.

\section{SH2 domain-containing proteins}

Many substrates for growth factor receptors contain a structural motif, Src homology 2 domain (SH2). These domains are present in dozens of intracellular proteins which either possess enzymatic activity, such as phospholipase $\mathrm{C} \alpha$ or phosphinositide-3-kinase, or function as bridging proteins (Grb2 and Shc). Bridging proteins recruit other signalling proteins, including son of sevenless (SOS) which in turn brings Ras into its active guanosine triphosphate binding form.

\section{Src family of non-receptor protein tyrosine kinases}

Several growth factors activate the Src family of kinases which again recruit and/or activate SH2-containing proteins, as well as phosphorylate many intracellular proteins.

\section{Ras/ MAP kinase}

Activated Ras translocates Raf-1 kinase to the plasma membrane, ultimately leading to a sequential activation of MAP kinase kinase signalling elements including MAP kinase (ERK1/2) and pp90rsk1.

\section{PKC}

Growth factor activation of phospholipase $\mathrm{C} \alpha$ increases inositol lipid turnover resulting in the generation of the second messenger, diacylglycerol. This in turn activates PKC, which phosphorylates and hence activates Raf-1 kinase.

\section{Protein phosphatases}

Signal transduction regulation is largely provided by the complex balance of protein kinases and their cognate phosphatases.

\section{Cyclins, cyclin-dependent kinases and casein kinase II}

End-point targets of growth factor signalling and key components of cell cycle regulation and survival.

\section{The AP-1 complex}

The activation of nuclear transcription factors by the various MAP kinase/PKC signalling pathways (ERK1/2, JNK and p38) regulate (Elk-1 and serum response factor), or indeed comprose (Fos and Jun) components of AP-1.

\section{Myc}

MAP kinase signalling activation of the nuclear transcription factor Myc, a key intermediate early response gene involved in growth response. 
association (Kraus et al. 1995, Pratt \& Toft 1997). Interestingly, while the activity of AF-2 appears to be largely ligand-enabled, showing relatively strict specificity for oestrogens, there is increasing evidence that AF1 activity is constitutive, a feature likely to derive from considerable ligand-independent (notably growth factor pathway-mediated) influences. Contributory growth signalling through other members of the steroid hormone nuclear transcription family utilise similar intracellular mechanisms to those described for the ER.

\section{Growth factor signalling}

Growth factor-induced signal transduction proceeds via a cascade of protein phosphorylation steps which serve to relay stimuli into cellular responses. Those events ultimately result in the induction/activation of multiple nuclear transcription factors, with an equally diverse range of target response elements, notably those in the promoters of genes orchestrating cell-cycle regulation and survival. Important elements in growth factor signalling also believed to influence, either directly or indirectly, ER signalling include those listed in Table 1.

\section{Cross-talk between ER and growth factor signalling pathways (Fig. 1)}

\section{Oestrogens stimulate positive elements of growth factor signalling pathways (Fig. 1-1)}

Oestrogen sensitivity and endocrine response have been extensively investigated in experimental models of human breast cancer both in vitro and in vivo. Based on these studies (reviewed in Gee et al. 1996, Nicholson \& Gee 1996), it is becoming increasingly evident that oestrogens can promote the autocrine expression of growth factor signalling pathway components, notably transforming growth factor (TGF)- $\alpha$ (Bates et al. 1988), insulin-like growth facor-II (IGF-II) (Brunner et al. 1993) and growth factor receptors (e.g. epidermal growth factor (EGF) receptor (EGFR) (Bertois et al. 1989, Chrysogelos et al. 1994) and IGF-I receptor (Freiss et al. 1990)), in oestrogen-responsive (MCF-7 and T47-D) and oestrogendependent (ZR-75-1) human breast cancer cell lines. Such actions, which are often antagonised by antioestrogens (reviewed in Gee et al. 1996, Nicholson \& Gee 1996), could significantly supplement the cellular growth responses directly primed by oestrogens (Cho \& Katzenellenbogen 1993, Smith et al. 1993).

In addition, it appears that oestrogens directly stimulate (while antioestrogens inhibit) the tyrosine kinase activities both of the EGFR-related protein c-erbB-2 (Matsuda et al. 1993) and of c-src (Migliaccio et al. 1993), the activation of which can provide important mitogenic signals to epithelial cells through the recruitment of the p21 ras/mitogen-activated protein (MAP) kinase pathway.

\section{Oestrogens inhibit negative elements of growth factor signalling pathways (Fig. 1-2)}

As well as the positive influences exerted by oestrogens on growth factor signalling pathways detailed above, it is notable that in parallel they diminish (while antioestrogens induce) the expression of the growth inhibitory factor TGF $\beta$ (Knabbe et al. 1987) in several oestrogenresponsive human breast cancer cell lines.

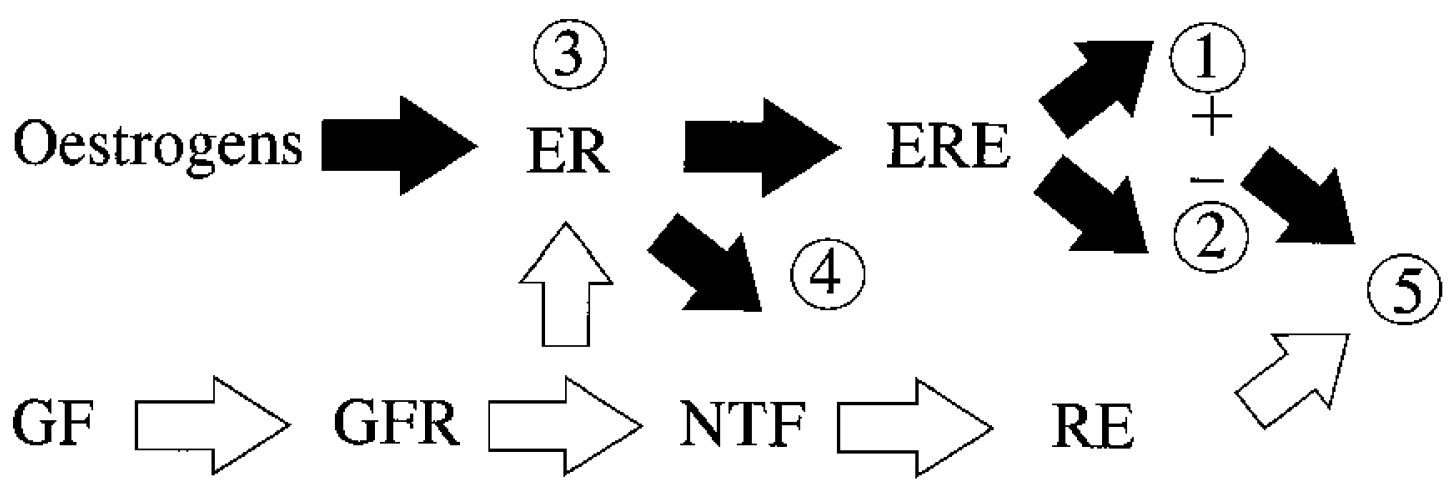

Figure 1 Cross-talk between ER and growth factor signalling pathways.

GF, growth factor; GFR, growth factor receptor; NTF; growth factor-induced nuclear transcription factor; RE; response element regulated by growth factor signalling pathways. 
Additionally, however, it is of particular significance that oestrogens can inhibit expression of tyrosine phosphatases in ER-positive breast cancer cells to increase growth factor mitogenic activity, while both steroidal and non-steroidal antioestrogens increase such enzyme activity. Tamoxifen, for example, inhibits the mitogenic activity of EGF by promoting significant dephosphory-lation of EGFR, an effect believed to be ER mediated (Freiss et al. 1990, Freiss \& Vignon 1994). It appears that such EGFR dephosphorylation is accomplished via an increase in tyrosine phosphatase activity, as evidenced not only by an effective inhibition by sodium orthovanadate, but furthermore by a time- and dose-dependent increase in membrane phosphatase activity with the antioestrogen (Freiss \& Vignon 1994). In this light, two tyrosine phosphatases have been identified which appear to be regulated by antioestrogens, LAR and FAP-1 respectively (Freiss et al. 1998). Significantly, antisense inhibition of FAP-1 expression abolishes the antioestrogen-mediated inhibition of growth factor mitogenic activity, although the 'pure' antioestrogen ICI 182,780 appears to retain inhibitory activity under these conditions, suggesting that the effects of this compound are FAP-1 independent (Freiss et al. 1998).

\section{ER is a target for growth factor-induced kinase activity (Fig. 1-3)}

Numerous studies have now shown that the ER is subject to phosphorylation and activation by several peptide growth factors (e.g. IGF-I (Aronica \& Katzenellenbogen 1993), EGF, TGF $\alpha$ (Bunone et al. 1996) and heregulin (Pietras et al. 1995)), events which can subsequently initiate ERE-mediated gene expression (Lee et al. 1997). Significantly, these elements appear to differentially activate AF-1 and AF-2, with the former being more responsive to $\mathrm{EGF}$ and $\mathrm{TGF} \alpha$ signalling (Bunone et al. 1996), and IGF-I preferentially targeting the latter (Gangolli et al. 1997). While activation by these factors occurs most efficiently in the presence of oestrogens, their promotion of AF-1 and AF-2 responses is certainly adequate for investigating transcription in the absence of the hormone. An emerging concept for steroid hormone receptors is therefore that they function not only as direct transducers of hormonal effects but, as members of the cellular nuclear transcription factor pool, also serve as key points of convergence for multiple signal trans-duction pathways (McDonnell et al. 1995).

Three serine residues (amino acids 104, 106 and 118) located within the AF-1 domain of ER, plus Ser-294, match the consensus sequence specific amino acid recognition motif targeted by a family of serine/threonine/ proline-directed kinases which include cyclin-dependent kinases and MAP kinases. Ser-104, -106 and -118 are phosphorylated upon oestrogen treatment (Ali et al. 1993, Le Goff et al. 1994), and mutation of these residues to alanine markedly decreases ligand-dependent transactivational activity. More detailed studies have recently confirmed that phosphorylation of Ser-118 is required for full activity of AF-1, and that MAP kinase is capable of this (Kato et al. 1995). Research shows the major oestradiol-induced phosphorylation site on the ER is Ser167 , and that this is phosphorylated by casein kinase II (Arnold et al. 1994, Tzeng \& Klinge 1996, Castano et al. 1997) and pp90rsk1 in a hormone-dependent manner (Joel et al. 1998). Furthermore, a direct role for the cyclin A/ cdk2 complex in phosphorylating the ER at a residue somewhere between amino acids 82 and 121 has also been suggested (Trowbridge et al. 1997). Similarly, protein kinase C (PKC)- $\delta$ targets the receptor at Ser-122 (Lahooti et al. 1998). Finally, the ER is also phosphorylated by p60c-src on tyrosine residues, in particular at Tyr-537 in the human protein (Arnold et al. 1997). This residue is located within the hormone-binding domain of the receptor and may serve to recruit coactivators (White \& Parker 1998), a class of molecules which in turn serve as substrates for cellular kinases and hence growth factor signalling. The bulk of evidence from other signal regulatory systems suggests the likely existence of phosphastases regulate ER-phosphorylating reactions; however the precise identities of these enzymes as yet await discovery.

Like oestrogens, antioestrogens can induce ER phosphorylation, albeit inefficiently (Ali et al. 1993, Aronica \& Katzenellenbogen 1993), and it is likely that this property contributes to the partial oestrogenicity exerted by some antioestrogens. It is also of particular significance that while antiestrogens appear to block AF-2 functions efficiently, they do not always prevent AF-1 activity (Berry et al. 1990). Since AF-1 functions are subject to ligand-independent regulation by growth factor signalling pathways, it has been suggested that inter-actions between elements of these pathways and antioestrogen-bound ER are necessary for the partial agonism of antioestrogens, and may represent a means whereby the oestrogenicity of these compounds may be exaggerated under conditions of excess growth factor stimulation (Kato et al. 1995, Bunone et al. 1996).

\section{ER interacts positively with growth factor- induced nuclear transcription factors (Fig. 1-4)}

As stated previously, an important feature of growth factor signalling is its potential to activate several profiles of nuclear transcription factors which subsequently serve to promote the expression of genes participating in a diversity of end-points, including cell cycle progression. Thus, the MAP kinase (ERK1/2) pathway leads not only to the phosphorylation of ER, but directly activates Elk-1 
(Gille et al. 1995). This latter transcription factor subsequently forms a ternary complex with serum response factor which primes Fos expression via the c-fos serum response element (Gille et al. 1995). Similarly, jun kinase (JNK) (also a member of the MAP kinase family) phosphorylates the c-Jun protein, which subsequently heterodimerises with Fos (Minden et al. 1994). The resultant complex, AP-1, is of central importance since it directly targets the 12-O tetradecanoyl-phorbol-13 acetate-responsive element, a sequence found in the promoters of many genes involved in a plethora of cellular end-points (Pfahl 1993).

In this light, it has been reported that oestrogens can significantly enhance growth factor-induced AP- 1 activity (Philips et al. 1993), a feature believed to be a consequence of productive protein/protein interactions between the ER and the AP-1 complex (Rochefort 1995). Indeed, $\alpha E R$ appears able to activate genes containing AP-1 sites in their promoters (Webb et al. 1995), providing a mechanism whereby ER signalling may be markedly diversified. Initial studies suggested that antiestrogens antagonised growth factor-induced AP-1 activity, with maximal inhibition by pure antiestrogens (Philips et al. 1993). However, subsequent investigations (albeit performed in uterine cells) have suggested that the tamoxifen/ ER complex may also act agonistically on promoters regulated by the AP-1 site (Webb et al. 1995).

\section{Steroid hormone and growth factor signalling pathways influence common growth regulatory genes (Fig. 1-5)}

In order for cells to proliferate, they initially need to be recruited into the cell cycle and then be induced to progress through it. These outcomes are orchestrated by at least two series of events which can be jointly influenced by steroid hormone and growth factor signalling pathways (Musgrove et al. 1993): firstly, the induction of intermediate early response genes, such as c-fos (Morishita et al. 1995, Duan et al. 1998), c-jun (Morishita et al. 1995, Mohamood et al. 1997) and c-myc (Dubik \& Shiu 1992, Musgrove et al. 1993), and secondly, the regulation of G1 cyclins (e.g. cyclin D1) and their partner kinases and inhibitors which are involved in restriction point control (Musgrove et al. 1993, Lukas et al. 1996). Joint activation of these pathways by oestrogens and growth factors would at a minimum reinforce mitogenic signals to responsive cells, and might even result in syner-gistic interactions between these overlapping pathways.

\section{Breast cancer phenotype and its potential influence on endocrine response}

The above data generated largely from model systems convincingly show that many points of convergence exist for oestrogen- and growth factor-mediated signalling pathways and hence that mitogenic responses potentially proceed more efficiently in a mixed oestrogen and growth factor milieu. However, the questions arise as to whether growth factors and their downstream signalling pathway components are detectable in clinical breast cancer and whether there is any evidence that aberrations in their signalling pathways may modify in vivo endocrine response. An increasing body of evidence is certainly supportive of an important role for many components of the erbB signalling pathway.

\section{TGF $\alpha$}

Enhanced production of TGF $\alpha$ has been observed in transformed rodent and human fibroblast and epithelial cells, where it may function as a downstream intermediary in the transformation pathway elicited by oncogenes (Salomon et al. 1990). It has been suggested that TGF $\alpha$ may act to induce hyperplastic responses in transformed breast cells, and thereby act as a promotional agent in combination with a normal background of mutational events (Matsui et al. 1990, Sandgren et al. 1990). Certainly, TGF $\alpha$ has been demonstrated to be present in readily detectable amounts in clinical breast cancer specimens (Ciardiello et al. 1991, Lundy et al. 1991, Umekita et al. 1992), where its increased expression has been related to primary endocrine insensitivity in ERpositive disease (Nicholson et al. 1994a). Furthermore, our recent examination of sequential clinical breast cancer biopsy specimens obtained during tamoxifen treatment is also supportive of elevated TGF $\alpha$ protein expression being involved in acquired endocrine resistance in ERpositive disease, while diminished expression appears to be a therapeutic feature of those patients exhibiting a good quality and longer duration of initial response (JMW Gee, JFR Robertson \& RI Nicholson, unpublished observations).

\section{The EGFR and c-erbB2 receptor tyrosine kinases}

Clinical data emerging in the late 1980s and early 1990s have convincingly shown a significant inverse relationship between the expression of the EGFR (reviewed in Klijn et al. 1992), and to a lesser extent c-erbB-2 protein (Nicholson et al. 1993, 1997), with the degree of endocrine sensitivity in breast cancer. Thus, while patients whose tumours expressed low levels of EGFR frequently benefited from antihormonal drugs such as tamoxifen, women whose tumours contained high numbers of binding sites for EGF/TGF $\alpha$ (Nicholson et al. 1989) or which demonstrated high levels of cell membrane-assoc-iated EGFR immunostaining (Nicholson et al. 1994b) rarely responded. Although to some degree these associations may be explained by the inverse relationship known to 
exist between the oestrogen and epidermal growth factor receptors, nevertheless some direct involve-ment of the EGFR in growth responses has been suggested, with increased EGFR level directly correlating both with elevated tumour proliferation and poor prognosis (Nicholson et al. 1997).

\section{Intracellular components of the MAP kinase pathway}

In clinical specimens, Sivaraman et al. (1997) demonstrated that hyperexpression of MAP kinase is a feature of clinical breast cancer. In this light, our own recent studies using specific antibodies which detect fully activated (i.e. dually phosphorylated) ERK1/2 have shown a highly significant relationship between their increased activation and a poorer quality and shorter duration of response to the antioestrogen tamoxifen, as well as with a reduced survival time in ER-positive patients (JMW Gee, JFR Robertson \& RI Nicholson, unpublished observations). Similarly, elevated levels and/or activity of additional intracellular molecules comprising or regulating the MAP kinase signalling pathway, including pp60c-src (Lehrer et al. 1989, Lawrence \& Niu 1998), Grb2 (Daly et al. 1994), RHAMM (Wang et al. 1998), Ras (Dati et al. 1991, Archer et al. 1995, Bland et al. 1995), Raf (Callans et al. 1995), PKC (Gordge et al. 1996) and the transcription factors c- myc (Borg et al. 1992, Kreipe et al. 1993, Shiu et al. 1993), PEA3 (Benz et al. 1997) and ESX (Chang et al. 1997) have also been noted in malignant breast.

\section{AP-1 signalling}

As previously stated, an important element in growth factor-induced cell proliferation is the induction and activation of the AP-1 complex (Davis 1995) and elevated expression of AP-1 activity has been observed in some human breast tumours, as compared with normal adjacent tissue (Linardopoulos et al. 1990). The Jun component of AP-1 is thus reported to be elevated in breast cancer (Tiniakos et al. 1994), and importantly there is an increasing body of in vitro and in vivo evidence to implicate the nuclear transcription factor Fos in the control of many processes associated with the neoplastic breast cell, most notably in its acquisition of endocrine independency and invasive capabilities. Thus, we have demonstrated significant associations between elevated Fos protein expression and increased proliferation, de novo endocrine insensitivity (Gee et al. 1995) and furthermore a worsened patient outlook in clinical breast cancer (Gee et al. 1995), also noted by Bland et al. (1995). Furthermore, our recent examination of sequential clinical breast cancer biopsy specimens obtained during tamoxifen treatment is also supportive of elevated Fos protein

\section{Antihormone Growth factors}

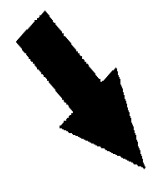

ER
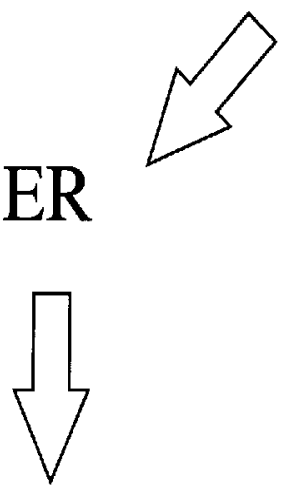

\section{Growth}

\section{A. Loss of ER \\ B. Aid ER signalling \\ C. Circumvent ER signalling}

Figure 2 Endocrine resistant disease. 
expression being involved in both primary and acquired endocrine resistance (Gee et al. 1999), while diminished Fos expression appears to be a therapeutic feature of patients with a good quality and longer duration of response. Our clinical findings demonstrating therapeutic increases in the Fos component of the AP-1 complex associated with endocrine resistance are mirrored by limited in vitro studies. As such, increased AP-1 DNA binding activity has been observed to be a feature of tamoxifen-resistant ER-positive breast cancer cells in vitro (Dumont et al. 1996), whilst prolonged tamoxifen exposure appears to render this antioestrogen agonistic in such cells via its augmentation of the phorbol esterinducible expression of a chimeric AP-1 response (Astruc et al. 1995, Badia et al. 1995).

\section{Derived model of endocrine response in breast cancer}

As detailed above, there is now substantial evidence that alterations in expression and/or activity of many growth factor signalling elements, notably those comprising the erbB pathway, are not uncommon in clinical breast cancer. Additionally, many of these aberrations appear to accurately mark (and hence may potentially be causative of) de novo or acquired endocrine resistance. In this light, a simple working model for the transition of endocrine responsive cancers such as those of the breast to endocrine insensitivity/resistance is suggested as follows.

\section{Endocrine responsive disease}

Input signals generated by steroid hormones and stimulatory growth factors are processed by endocrine-responsive, ER-positive cells to ultimately induce/activate several classes of nuclear transcription factors (e.g. steroid hormone receptor, AP-1, Myc etc.). Such inductive events are not autonomous: they are markedly strengthened by the close interplay of the relevant signalling pathways, a feature also noted in normal breast. The sum effect of this activation is to influence patterns of gene expression, leading to the efficient gain of positive influences on cellcycle progression (e.g. via cyclin D1), with a parallel suppression of negative influences (e.g. TGF $\beta$ ). In the presence of adequate steroid hormone and growth factor input signals, cells are subsequently recruited into the cell cycle and successfully proceed through it, resulting in growth. Such pathways are also central to mitogenic events in the normal breast.

Thus, although it is likely that cross-talk between both steroid and growth factor pathways increases mitogenic efficiency, substantial reduction in the input signals and hence in resultant cell proliferation can be elicited either by treatment with antihormones or via depletion of the oestrogenic environment alone, thereby potentially lead- ing to excellent initial tumour remissions. These data certainly support the clinical existence of a population of strictly steroid hormone-dependent tumours, deriving their mitogenic stimuli primarily from the influences of the oestrogen-activated ER.

\section{Endocrine resistant disease}

Three mechanisms are postulated for the development of endocrine resistance (Fig. 2).

\section{Loss of ER}

ER negativity is predictably associated with de novo endocrine resistance, comprising some $30 \%$ of tumours at presentation. It is as yet unknown if such a phenotype arises from aberrant loss of the steroid hormone receptor, or if such tumours merely arise from the outgrowth of the ER-negative/EGFR-positive cells known to exist in the normal mammary epithelium (Walker et al. 1991, 1992). Whatever the mechanism, it is believed that regulation of such tumours is severed from the oestrogenic environment and that they are initially wholly dependent on growth factor signalling for their mitogenic responses (Nicholson et al. 1997).

\section{Retention of ER but aberrant growth factor signalling alters steroid hormone sensitivity}

In such tumours it is postulated that changed growth factor signalling elements within the cancer phenotype significantly impinge on ER-directed events such that cells are able to survive and prosper under conditions where only limited amounts of oestrogens are available to the receptor or where it is occupied by antihormonal drugs. Such a mechanism may contribute to both de novo and acquired endocrine resistance and is consistent with the (re)expression of ER-regulated genes in these conditions and the favourable clinical responses noted in many patients challenged with a second-line endocrine therapy.

\section{Retention of ER but aberrant growth factor signalling circumvents the need for steroid hormone-driven growth responses}

Here aberrations in growth factor signalling elements are envisaged as occurring at points which are downstream of those directly affecting ERs, but which are part of the cellular response pathways used by both growth factors and steroid hormones for promoting tumour growth. Such cancers would not normally be expected to respond to second-line endocrine measures.

\section{New therapeutic targets}

Based on the above model for loss of endocrine response in breast cancer, several therapeutic approaches can be envisaged which may delay the appearance of, or even 
treat, endocrine insensitivity/resistance, hence severely compromising the disease process. These include the targeting of the following.

\section{ER: pure antioestrogens and anti-steroid hormone receptor regimes}

The most efficient theoretical means of eliminating the influences of pathway 'cross-talk' occurrent via ER would be to reduce cellular levels of this receptor. In this light, we (Nicholson et al. 1995a), and others (Gibson et al. 1991, Dauvois et al. 1992), have recognised ER downregulation as a property of pure antioestrogens which is not shared by other antihormonal drugs. Indeed, these agents are certainly more potent than tamoxifen at promoting tumour remissions in several models of human breast cancer, additionally inhibiting growth factor-induced cell proliferation in both oestrogen-sensitive and resistant ER-positive breast cancer cells (Nicholson et al. $1995 a, b)$. In parallel, pure antioestrogens appear highly effective in diminishing the cellular ER level and associated expression of oestrogen-regulated mRNAs and proteins in clinical breast cancer specimens (DeFriend et al. 1994, McClelland et al. 1996), and can furthermore promote long-lasting tumour remissions in patients who have developed tamoxifen resistance (Howell et al. 1995, 1996).

Importantly, however, the ER protein is eventually reexpressed at significant levels within pure antioestrogentreated cells, an event which coincides with an upregulation of oestrogen-regulated gene expression and the development of a pure antioestrogen-resistant state (Larsen et al. 1997). Although the mechanisms associated with the regain of these cellular functions are as yet unknown, ER re-expression coincident with the development of resistance may again imply that additional therapeutic benefit may accrue from re-instigating receptor loss. In this light, we are currently exploring the feasibility of using gene inhibition strategies to further reduce the intracellular activity of the ER. These strategies employ anti-sense technologies (to inhibit ER expression) and ER-dominant negative mutants (to interfere with ER protein function). Certainly, the transient expression of a truncated version of the ER protein (DNER-1), which notably lacks the C-terminal hormone binding and AF-2 domains of the receptor, reduces the ability of the wildtype ER protein to transactivate ERE reporter gene constructs in co-transfected ER-positive breast cancer cell lines (TA Madden \& RI Nicholson, unpublished observations).

\section{Growth factor receptors: anti-ligand and receptor regimes}

Given the role established for erbB tyrosine kinase receptors in the regulation of breast cell proliferation, a number of approaches have been used to reduce the signalling primed by EGFR and c-erbB- 2 within cancer cells.

Several groups have successfully employed immunotherapy with monoclonal antibodies specifically targeting the EGFR or c-erbB-2 proteins to disrupt their subsequent signalling and prevent autocrine loops (Ennis et al. 1991, Baselga et al. 1996, Kolibaba \& Druker 1997). Growth inhibition of EGFR and c-erbB2 overexpressing tumours can thereby be enabled both in vitro and in vivo (Dean et al. 1994, Eccles et al. 1994). Indeed, phase II clinical trials with a humanised anti-erbB-2 antibody performed on node-positive breast cancer patients showed an overall response rate of 12\% (Baselga et al. 1996). Additionally, such antibodies (or antibody fragments) have also been used to deliver drugs, radiation or prodrug-activating enzymes (Harris 1997), in each instance with some evidence of therapeutic benefit. Finally, toxin conjugates of relevant ligands that damage erbB-expressing cells have also been described (Ennis et al. 1991, Tang et al. 1994, Fiddes et al. 1995, Jeschke et al. 1995, Siegall et al. 1995, Osborne \& Coronado-Heinsohn 1996), as have appropriate antisense mRNA strategies (Casalini et al. 1997).

Other ways to exploit tumour dependency on growth factor signalling has been to (i) block ligand binding to receptors, using agents such as the trypanocidal drug suramin (Eisenberger et al. 1995) or its derivatives (Gagliardi et al. 1998) and (ii) use cell-permeable low molecular weight inhibitors specific to a particular tyrosine protein kinase (Kelloff et al. 1996). Potential inhibitors of protein kinases include ATP analogues and peptide-based inhibitors, including those competing for the SH2 domain (reviewed in Lawrence \& Niu 1998). Of particular promise are the tyrosine-specific protein kinase inhibitors, notably tyrophostins (Lawrence \& Niu 1998) and more recently quinazoline derivatives (Ward et al. 1994, Wakeling et al. 1997), while several naturally occurring compounds may also be relevant (e.g. erbstatin (Toi et al. 1990, Umezawa 1995, Wiechen \& Dietel 1995), lavendustin A (Onoda et al. 1989) and genistein (Clark et al. 1996)). Encouragingly, quinazolines not only specifically block the growth-promoting effects of EGFR ligands applied exogenously in culture (Fry et al. 1994, Wakeling et al. 1996, Jones et al. 1997), but have also been shown in a number of cases to reduce basal growth under serumfree conditions (Jones et al. 1997). Therefore, while it appears that many such cells are certainly capable of synthesising and secreting ligands which can activate the EGFR in an autocrine manner, it is nevertheless likely that such pathways may be equally susceptible to the inhibitory properties of these new compounds, where they may also fortuitously instigate programmed cell death. Additionally, EGFR-selective tyrosine kinase inhibitors 
when used at high concentrations in vitro can (i) block the cellular actions of oestrogens on breast cancer cells (Wakeling et al. 1996), (ii) reduce the growth of ERpositive oestrogen-growth independent (i.e. resistant) cells (Nicholson et al. 1995b) and (iii) show additive inhibitory properties when combined with antioestrogens (RI Nicholson, unpublished observations).

\section{Signal transduction pathways}

An extensive biological evaluation of the cellular effects of various inhibitors of individual downstream elements in growth factor signalling pathways is being undertaken by numerous groups (see Heimbrook \& Oliff 1998). However, of particular interest are Ras protein inhibitors, which either inactivate the enzymes that catalyse its posttranslational modification (e.g. farnesyl protein transferase (Kohl et al. 1995, Reuveni et al. 1997)) or which act to lower Ras mRNA levels through the use of anti-sense oligonucleotides and ribozymes (Monia et al. 1992, Kawada et al. 1997, Scherr et al. 1997). Many naturally occurring compounds also inhibit Ras function, often by preventing association with the membrane, including a Vinca alkaloid (Umezawa et al. 1994), squalene (found in olive oil (Newmark 1997)), diallyl disulfide (found in garlic (Singh et al. 1996)) and damnacanthal (Hiramatsu et al. 1993).

Ras-inhibitory compounds, like EGFR-selective tyrosine kinase inhibitors, might be expected to influence both steroid hormone and growth factor signalling, as would pharmacological and anti-sense inhibitors of PKC (Philip \& Harris 1995, Melner 1996, Kobayashi et al. 1997, McGraw et al. 1997, Geiger et al. 1998), Raf (Monia 1997), MAP kinase (Alessi et al. 1995, Amundadottir \& Leder 1998) and c-src (Hori et al. 1992, Levitzki 1996). In our own hands, inhibition of MAP kinase activity by the compound PD098059 is effective not only as a means of reducing growth factor-driven proliferative responses within ER-positive breast cancer cells, but also to inhibit ER activation of ERE reporter gene constructs following transient transfection. Equally, PD098059 blocks (i) MAP kinase-induced expression of the early intermediate response gene Fos, (ii) the subsequent activation of AP-1mediated signalling (see below), (iii) productive associations between steroid hormone and growth factor signalling pathways in driving gene responses and (iv) oestrogen and growth factor-promoted proliferation of the cells.

\section{Nuclear transcription factors}

Potentially useful anti-tumour effects can be generated in breast cancer cells in vitro through the inhibition of AP-1 signalling. Relevant inhibitory agents include glucocorticoids (Jonat et al. 1990, Kerppola et al. 1993, Huang et al. 1997) and retinoids (Nicholson et al. 1990), as well as AP1 dominant negative (Olive et al. 1997) and anti-sense strategies (Holt et al. 1996). In a number of instances, it has been shown that compounds such as all-trans retinoic acid not only have anti-proliferative activity, as mediated by inhibition of AP-1 activity, but importantly that they may also be potent inducers of apoptosis (Mangiarotti et al. 1998). We have observed that all-trans retinoic acid efficiently blocks growth factor-mediated expression of Fos protein and AP-1 activity in breast cancer cells in vitro. Such inhibition appears sufficient to prevent the growth-promoting effects of oestrogens and furthermore aids the inhibitory effects of antioestrogens (RA McClelland \& RI Nicholson, unpublished observations). Such data certainly imply significant and therapeutically exploitable cross-talk between these pathways, and that combination therapy of antihormones and retinoids may be appropriate. It is noteworthy that several laboratories have developed synthetic retinoids that can selectively target AP-1 signalling without activating transcription of retinoid-regulated genes (Chen et al. 1995, Nagpal et al. 1995, Fanjul et al. 1996, Agadir et al. 1997, Huang et al. 1997). Indeed, since such compounds can synergise with glucocorticoids to efficiently repress phorbol esterinduced AP-1 activity (Chen et al. 1995), they may find an expanding role in the therapy of those endocrine responsive and unresponsive cancers which show increased reliance on AP-1 signalling. Finally, many naturally occurring microbial and plant extracts and their derivatives may be of future use. Of particular note are the momordins (Lee et al. 1998) and curcumin (diferuloylmethane). These agents inhibit AP-1 activity (Bierhaus et al. 1997, Pendurthi et al. 1997, Xu et al. 1997), the latter compound inducing an unstable, hyperphosphorylated Fos protein (Huang et al. 1995) to inhibit proliferation and elicit programmed cell death (Chen \& Huang 1998).

\section{Summary and conclusions}

Signalling of steroid hormone and growth factor pathways and their key components is far from simplistic, with an elaborate molecular and protein biology and a diverse regulation encompassing a network of phosphorylation cascades. It is becoming increasingly apparent that there are additional layers of complexity to such signalling, with the pathways being intimately linked rather than autonomous. Indeed, several points of productive cross-talk between steroid hormone- and growth factor-directed pathways have now been identified in oestrogenresponsive cells which are believed to markedly reinforce their individual cellular effects on growth and gene responses. It is thus postulated that aberrations occurrent in growth factor signalling pathways could dramatically influence/circumvent steroid hormone action. Certainly, altered elements of growth factor signalling pathways are a relatively common phenotypic characteristic of clinical and experimental breast cancer, a feature which correlates 
with the development of endocrine insensitivity in both the de novo and acquired setting. A projected paradigm, therefore, is that inhibitory agents (either synthetically or naturally derived) directed towards reducing the influence of growth factors, or of their intracellular signalling pathway components, may prove of clinical benefit in the therapy of breast tumours exhibiting resistance to antihormonal measures or may delay the appearance of these deleterious conditions. With the recent and contin-ued expansion of available technologies and an increasing battery of available pharmacological and molecular therapeutic agents, such targeting of aberrant growth factor signalling is now becoming a genuine possibility, and may eventually be applicable to many tumour types.

\section{References}

Agadir A, Shealy YF, Hill DL \& Zhang X 1997 Retinyl methyl ether down-regulates activator protein 1 transcriptional activation in breast cancer cells. Cancer Research $573444-$ 3450 .

Alessi DR, Cuenda A, Cohen P, Dudley DT \& Saltiel AR 1995 PD 098059 is a specific inhibitor of the activation of mitogenactivated protein kinase in vitro and in vivo. Journal of Biological Chemistry 270 27489-27494.

Ali S, Metzger D, Bornert JM \& Chambon P 1993 Modulation of transcriptional activation by ligand-dependent phosphorylation of the human oestrogen receptor $\mathrm{A} / \mathrm{B}$ region. $E M B O$ Journal 12 1153-1160.

Amundadottir LT \& Leder P 1998 Signal transduction pathways activated and required for mammary carcinogenesis in response to specific oncogenes. Oncogene 16 737-746.

Archer SG, Eliopoulos A, Spandidos D, Barnes D, Ellis IO, Blamey RW, Nicholson RI \& Robertson JFR 1995 Expression of Ras p21, p53 and c-erbB-2 in advanced breast cancer and response to first line hormonal therapy. British Journal of Cancer 72 1259-1266.

Arnold SF, Obourn JD, Jaffe H \& Notides AC 1994 Serine 167 is the major estradiol-induced phosphorylation site on the human estrogen receptor. Molecular Endocrinology 8 12081214.

Arnold SF, Melamed M, Vorojeikina DP, Notides AC \& Sasson S 1997 Estradiol-binding mechanism and binding capacity of the human estrogen receptor is regulated by tyrosine phosphorylation. Molecular Endocrinology 11 48-53.

Aronica SM \& Katzenellenbogen BS 1993 Stimulation of estrogen receptor-mediated transcription and alteration in the phosphorylation state of the rat uterine estrogen receptor by estrogen, cyclic adenosine monophosphate, and insulin-like growth factor-I. Molecular Endocrinology 7 743-752.

Astruc ME, Chabret C, Bali P, Gagne D \& Pons M 1995 Prolonged treatment of breast cancer cells with antiestrogens increases the activating protein-1-mediated response: involvement of the estrogen receptor. Endocrinology 136824 832.

Badia E, Duchesne MJ, Astruc M, Fuentes M, Gagne D, Nicolas JC \& Pons M 1995 Modulation of cellular response expression during prolonged treatment with antiestrogens. Comptes Rendus des Seances de la Societe de Biologie et de ses Filiales 189 755-764.

Baselga J, Tripathy D, Mendelsohn J, Baughman S, Benz CC, Dantis L, Sklarin NT, Seidman AD, Hudis CA, Moore J, Rosen PP, Twaddell T, Henderson IC \& Norton L 1996 Phase II study of weekly intravenous recombinant humanized antip185HER2 monoclonal antibody in patients with HER2/neuoverexpressing metastatic breast cancer. Journal of Clinical Oncology 14 737-744.

Bates SE, Davidson NE, Valverius EM, Freter CE, Dickson RB, Tam JP, Kudlow JE, Lippman ME \& Salomon DS 1988 Expression of transforming growth factor-alpha and its mRNA in human breast cancer: Its regulation by oestrogen and its possible functional significance. Molecular Endocrinology 2 543-555.

Benz CC, O'Hagan RC, Richter B, Scott GK, Chang CH, Xiong $\mathrm{X}$, Chew K, Ljung BM, Edgerton S, Thor A \& Hassell JA 1997 HER2/Neu and the Ets transcription activator PEA3 are coordinately upregulated in human breast cancer. Oncogene 15 1513-1525.

Berry M, Metzger D \& Chambon P 1990 Role of two activating domains of the oestrogen receptor in the cell-type and promoter-context dependent agonistic activity of the antioestrogen 4-hydroxytamoxifen. EMBO Journal 9 2811-2818.

Berthois Y, Dong XF \& Martin PM 1989 Regulation of epidermal growth factor receptor by oestrogen and antioestrogen in the human breast cancer cell line MCF-7. Biochemical and Biophysical Research Communications 159 126-131.

Bierhaus A, Zhang Y, Quehenberger P, Luther T, Haase M, Muller M, Mackman N, Ziegler R \& Nawroth PP 1997 The dietary pigment curcumin reduces endothelial tissue factor gene expression by inhibiting binding of AP- 1 to the DNA and activation of NF-kappa B. Thrombosis und Haemostasis $\mathbf{7 7}$ 772-782.

Bland KI, Konstadoulakis MM, Vezeridis MP \& Wanebo HJ 1995 Oncogene protein co-expression. Value of Ha-ras, cmyc, c-fos, and p53 as prognostic discriminants for breast carcinoma. Annals of Surgery 221 706-718.

Borg A, Baldetorp B, Ferno M, Olsson H \& Sigurdsson H 1992 c-myc amplification is an independent prognostic factor in postmenopausal breast cancer. International Journal of Cancer 51 687-691.

Brunner N, Yee D, Kern FG, Spang-Thomsen M, Lippman ME \& Cullen KJ 1993 Effect of endocrine therapy on growth of T61 human breast cancer xenografts is directly correlated to a specific down-regulation of insulin-like growth factor II (IGFII). European Journal of Cancer 29 562-569.

Bunone G, Briand PA, Miksicek RJ \& Picard D 1996 Activation of the unliganded estrogen receptor by EGF involves the MAP kinase pathway and direct phosphorylation. EMBO Journal 15 2174-2183.

Callans LS, Naama H, Khandelwal M, Plotkin R \& Jardines L 1995 Raf-1 protein expression in human breast cancer cells. Annals of Surgical Oncology 2 38-42.

Casalini P, Menard S, Malandrin SM, Rigo CM, Colnaghi MI, Cultraro CM \& Segal S 1997 Inhibition of tumorigenicity in 
lung adenocarcinoma cells by c-erbB-2 antisense expression. International Journal of Cancer 72 631-636.

Castano E, Vorojeikina DP \& Notides AC 1997 Phosphorylation of serine-167 on the human oestrogen receptor is important for oestrogen response element binding and transcriptional activation. Biochemical Journal 326 149-157.

Chang CH, Scott GK, Kuo WL, Xiong X, Suzdaltseva Y, Park JW, Sayre P, Erny K, Collins C, Gray JW \& Benz CC 1997 ESX: a structurally unique Ets overexpressed early during human breast tumorigenesis. Oncogene 14 1617-1622.

Chen HW \& Huang HC 1998 Effect of curcumin on cell cycle progression and apoptosis in vascular smooth muscle cells. British Journal of Pharmacology 124 1029-1040.

Chen JY, Penco S, Ostrowski J, Balaguer P, Pons M, Starrett JE, Reczek P, Chambon P \& Gronemeyer H 1995 RAR-specific agonist/antagonists which dissociate transactivation and AP1 transrepression inhibit anchorage-independent cell proliferation. EMBO Journal 14 1187-1197.

Cho H \& Katzenellenbogen BS 1993 Synergistic activation of estrogen receptor-mediated transcription by estradiol and protein kinase activators. Molecular Endocrinology 7441 452.

Chrysogelos SA, Yarden RI, Lauber AH \& Murphy JM 1994 Mechanisms of EGF receptor regulation in breast cancer cells. Breast Cancer Research and Treatment 31 227-236.

Ciardiello F, Kim N, McGeady ML, Liscia DS, Saeki T, Bianco \& Salomon DS 1991 Expression of transforming growth factor alpha in breast cancer. Annals of Oncology 2 169-182.

Clark JW, Santos-Moore A, Stevenson LE \& Frackelton AR Jr 1996 Effects of tyrosine kinase inhibitors on the proliferation of human breast cancer cell lines and proteins important in the Ras signaling pathway. International Journal of Cancer $\mathbf{6 5}$ 186-191.

Clarke RB, Howell A, Potten CS \& Anderson E 1997 Dissociation between steroid receptor expression and cell proliferation in the human breast. Cancer Research 57 49874991.

Daly RJ, Binder MD \& Sutherland RL 1994 Overexpression of the Grb2 gene in human breast cancer cell lines. Oncogene 9 2723-2727.

Dati C, Muraca R, Tazartes O, Antoniotti S, Perroteau I, Giai M, Cortese P, Sismondi P, Saglio G \& De Bortoli M 1991 c-erbB2 and ras expression levels in breast cancer are correlated and show a co-operative association with unfavorable clinical outcome. International Journal of Cancer 47 833-838.

Dauvois S, Danielian PS, White R \& Parker MG 1992 Antiestrogen ICI 164,384 reduces cellular estrogen receptor content by increasing its turnover. Proceedings of the National Academy of Sciences of the USA 89 4037-4041.

Davis RJ 1995 Transcriptional regulation by MAP kinases. Molecular Reproduction and Development 42 459-467.

Dean C, Modjtahedi H, Eccles S, Box G \& Styles J 1994 Immunotherapy with antibodies to the EGF receptor. International Journal of Cancer 8 (Suppl) 103-107.

DeFriend DJ, Howell A, Nicholson RI, Anderson E, Dowsett M, Mansel RE, Blamey RW, Bundred NJ, Robertson JF, Saunders C \& Baum M 1994 Investigation of a new pure antiestrogen
(ICI 182780) in women with primary breast cancer. Cancer Research 54 408-414.

Diamond MI, Miner JN, Yoshinaga SK \& Yamamoto KR 1990 Transcription factor interactions: selectors of positive or negative regulation from a single DNA element. Science $\mathbf{2 4 9}$ 1266-1272.

Duan R, Porter W \& Safe S 1998 Estrogen-induced c-fos protooncogene expression in MCF-7 human breast cancer cells: role of estrogen receptor $\mathrm{Sp} 1$ complex formation. Endocrinology 139 1981-1990.

Dubik D \& Shiu RP 1992 Mechanism of estrogen activation of c-myc oncogene expression. Oncogene 7 1587-1594.

Dumont JA, Bitonti AJ, Wallace CD, Baumann RJ, Cashman EA \& Cross-Doersen DE 1996 Progression of MCF-7 breast cancer cells to antiestrogen-resistant phenotype is accompanied by elevated levels of AP-1 DNA-binding activity. Cell Growth and Differentiation 7 351-359.

Eccles SA, Modjtahedi H, Box G, Court W, Sandle J \& Dean CJ 1994 Significance of the c-erbB family of receptor tyrosine kinases in metastatic cancer and their potential as targets for immunotherapy. Invasion Metastasis 14 337-348.

Eisenberger MA, Sinibaldi V \& Reyno L 1995 Suramin. Cancer Practice 3 187-189.

Ennis BW, Lippman ME \& Dickson RB 1991 The EGF receptor system as a target for antitumor therapy. Cancer Investigation 9 553-562.

Fanjul AN, Bouterfa H, Dawson MI \& Pfahl MA 1996 Potential role for retinoic acid receptor-gamma in the inhibition of breast cancer cells by selective retinoids and interferons. Cancer Research 56 1571-1577.

Fiddes RJ, Janes PW, Sanderson GM, Sivertsen SP, Sutherland RL \& Daly RJ 1995 Heregulin (HRG)-induced mitogenic signaling and cytotoxic activity of a HRG/PE40 ligand toxin in human breast cancer cells. Cell Growth and Differentiation 6 1567-1577.

Freiss G \& Vignon F 1994 Antiestrogens increase protein tyrosine phosphatase activity in human breast cancer cells. Molecular Endocrinology 8 1389-1396.

Freiss G, Prebois C, Rochefort H \& Vignon F 1990 Anti-steroidal and anti-growth factor activities of anti-oestrogens. Journal of Steroid Biochemistry and Molecular Biology 37 777-781.

Freiss G, Puech C \& Vignon F 1998 Extinction of insulin-like growth factor-I mitogenic signaling by antiestrogenstimulated Fas-associated protein tyrosine phosphatase- 1 in human breast cancer cells. Molecular Endocrinology 12 568579.

Fry DW, Kraker AJ, McMichael A, Ambroso LA, Nelson JM, Leopold WR, Connors RW \& Bridges AJ 1994 A specific inhibitor of the epidermal growth factor receptor tyrosine kinase. Science 265 1093-1095.

Gagliardi AR, Kassack M, Kreimeyer A, Muller G, Nickel P \& Collins DC 1998 Antiangiogenic and antiproliferative activity of suramin analogues. Cancer Chemotherapy and Pharmacology 41 117-124.

Gangolli EA, Conneely OM \& O'Malley BW 1997 Neurotransmitters activate the human estrogen receptor in a neuroblastoma cell line. Journal of Steroid Biochemistry and Molecular Biology 61 1-9. 
Gee JMW, Ellis IO, Robertson JFR, Willsher P, McClelland RA, Hewitt KN, Blamey RW \& Nicholson RI 1995 Immunocytochemical localization of FOS protein in human breast cancers and its relationship to a series of prognostic markers and response to endocrine therapy. International Journal of Cancer 64 269-273.

Gee JWM, McClelland RA \& Nicholson RI 1996 Growth factors and endocrine sensitivity in breast cancer. In Hormone Dependent Cancer, pp 169-197. Eds JR Pasqualini \& BS Katzenellenbogen. Marcel Dekker Publishing.

Gee, JMW, Willsher P, Kenny FS, Robertson JFR, Pinder SE, Ellis IO \& Nicholson RI 1999 Endocrine response and resistance in breast cancer: A role for the transcription factor FOS. International Journal of Cancer 84 54-61.

Geiger T, Muller M, Dean NM \& Fabbro D 1998 Antitumor activity of a PKC-alpha antisense oligonucleotide in combination with standard chemotherapeutic agents against various human tumors transplanted into nude mice. Anti Cancer Drug Design 13 35-45.

Gibson MK, Nemmers LA, Beckman WC Jr, Davis VL, Curtis SW \& Korach KS 1991 The mechanism of ICI 164,384 antiestrogenicity involves rapid loss of estrogen receptor in uterine tissue. Endocrinology 129 2000-2010.

Gille H, Kortenjann M, Thomae O, Moomaw C, Slaughter C, Cobb MH \& Shaw PE 1995 ERK phosphorylation potentiates Elk-1-mediated ternary complex formation and transactivation. EMBO Journal 14 951-962.

Gordge PC, Hulme MJ, Clegg RA \& Miller WR 1996 Elevation of protein kinase $\mathrm{A}$ and protein kinase $\mathrm{C}$ activities in malignant as compared with normal human breast tissue. European Journal of Cancer 32A 2120-2126.

Harris AL 1997 EGF Receptor as a target for therapy and interactions with angiogenesis. In EGF Receptor in Tumor Growth and Progression, pp 3-17. Eds RB Lichtner \& RN Harkins. Ernst Schering Research Foundation Workshop 19. Berlin, Heidelberg: Springer-Verlag.

Heimbrook DC \& Oliff A 1998 Therapeutic intervention and signaling. Current Opinion in Cell Biology 10 284-288.

Hiramatsu T, Imoto M, Koyano T \& Umezawa K 1993 Induction of normal phenotypes in ras-transformed cells by damnacanthal from Morinda citrifolia. Cancer Letters 73 161-166.

Holt JT, Arteaga CB, Robertson D \& Moses HL 1996 Gene therapy for the treatment of metastatic breast cancer by in vivo transduction with breast-targeted retroviral vector expressing antisense c-fos RNA. Human Gene Therapy 7 1367-1380.

Hori T, Kondo T, Tsuji T, Imoto M, Umezawa K, Ekimoto H \& Hiratsuka M 1992 Inhibition of tyrosine kinase and src oncogene functions by stable erbstatin analogues. Journal of Antibiotics 45 280-282.

Howell A, DeFriend D, Robertson J, Blamey R \& Walton P 1995 Response to a specific antioestrogen (ICI 182780) in tamoxifen-resistant breast cancer. Lancet 345 29-30.

Howell A, DeFriend DJ, Robertson JF, Blamey RW, Anderson L, Anderson E, Sutcliffe FA \& Walton P 1996 Pharmacokinetics, pharmacological and anti-tumour effects of the specific antioestrogen ICI 182780 in women with advanced breast cancer. British Journal of Cancer 74 300-308.
Howell A, Clarke RB \& Anderson E 1997 Oestrogens, Beatson and endocrine therapy. Endocrine-Related Cancer 4 371-380.

Huang C, Ma WY, Dawson MI, Rincon M, Flavell RA \& Dong Z 1997 Blocking activator protein-1 activity, but not activating retinoic acid response element, is required for the antitumor promotion effect of retinoic acid. Proceedings of the National Academy of Sciences of the USA 94 5826-5830.

Huang TS, Kuo ML, Lin JK \& Hsieh JS 1995 A labile hyperphosphorylated c-Fos protein is induced in mouse fibroblast cells treated with a combination of phorbol ester and anti-tumor promoter curcumin. Cancer Letters 96 1-7.

Jeschke M, Wels W, Dengler W, Imber R, Stocklin E \& Groner B 1995 Targeted inhibition of tumor-cell growth by recombinant heregulin-toxin fusion proteins. International Journal of Cancer 60 730-739.

Joel PB, Smith J, Sturgill TW, Fisher TL, Blenis J \& Lannigan DA 1998 pp90rsk1 regulates estrogen receptor-mediated transcription through phosphorylation of Ser-167. Molecular and Cellular Biology 18 1978-1984.

Jonat C, Rahmsdorf HJ, Park KK, Cato AC, Gebel S, Ponta H \& Herrlich P 1990 Antitumor promotion and antiinflammation: down-modulation of AP-1 (Fos/Jun) activity by glucocorticoid. Cell 62 1189-2104.

Jones HE, Dutkowski CM, Barrow D, Harper ME, Wakeling AE \& Nicholson RI 1997 New EGF-R selective tyrosine kinase inhibitor reveals vriable growth responses in prostate carcinoma cell lines PC-3 and DU-145. International Journal of Cancer 71 1010-1018.

Kato S, Endoh H, Masuhiro Y, Kitamoto T, Uchiyama S, Sasaki H, Masushige S, Gotoh Y, Nishida E \& Kawashima H 1995 Activation of the estrogen receptor through phosphorylation by mitogen-activated protein kinase. Science 270 1491-1494.

Kawada M, Fukazawa H, Mizuno S \& Uehara Y 1997 Inhibition of anchorage-independent growth of ras-transformed cells on polyHEMA surface by antisense oligodeoxynucleotides directed against K-ras. Biochemical and Biophysical Research Communications 231 735-737.

Kelloff GJ, Fay JR, Steele VE, Lubet RA, Boone CW, Crowell JA \& Sigman CC 1996 Epidermal growth factor receptor tyrosine kinase inhibitors as potential cancer chemopreventives. Cancer Epidemiology Biomarkers and Prevention 5 657-666.

Kerppola TK, Luk D \& Curran T 1993 Fos is a preferential target of glucocorticoid receptor inhibition of AP-1 activity in vitro. Molecular and Cellular Biology 13 3782-3791.

Klijn JG, Berns PM, Schmitz PI \& Foekens JA 1992 The clinical significance of epidermal growth factor receptor (EGF-R) in human breast cancer: a review on 5232 patients. Endocrine Reviews 13 3-17.

Knabbe C, Lippman ME, Wakefield LM, Flanders KC, Kasid A, Derynck R \& Dickson RB 1987 Evidence that transforming growth factor-beta is a hormonally regulated negative growth factor in human breast cancer cells. Cell 48 417-428.

Kobayashi D, Watanabe N, Yamauchi N, Tsuji N, Sato T, Sasaki H, Okamoto T \& Niitsu Y 1997 Protein kinase C inhibitors augment tumor-necrosis-factor-induced apoptosis in normal human diploid cells. Chemotherapy $\mathbf{4 3}$ 415-423. 
Kohl NE, Conner MW, Gibbs JB, Graham SL, Hartman GD \& Oliff A 1995 Development of inhibitors of protein farnesylation as potential chemotherapeutic agents. Journal of Cellular Biochemistry 22 (Suppl) 145-150.

Kolibaba KS \& Druker BJ 1997 Protein tyrosine kinases and cancer. Biochimica et Biophysica Acta 1333 F217-F248.

Kraus WL, McInerney EM \& Katzenellenbogen BS 1995 Ligand-dependent, transcriptionally productive association of the amino- and carboxyl-terminal regions of a steroid hormone nuclear receptor. Proceedings of the National Academy of Sciences of the USA 92 12314-12318.

Kreipe H, Feist H, Fischer L, Felgner J, Heidorn K, Mettler L \& Parwaresch R 1993 Amplification of c-myc but not of c-erbB2 is associated with high proliferative capacity in breast cancer. Cancer Research 53 1956-1961.

Kuiper GGJM \& Brinkmann AO 1994 Steroid hormone receptor phosphorylation: is there a physiological role? Molecular and Cellular Endocrinology 100 103-107.

Kumar V, Green S, Stack G, Berry M, Jin JR \& Chambon P 1987 Functional domains of the human estrogen receptor. Cell $\mathbf{5 1}$ 941-951.

Lahooti H, Thorsen T \& Aakvaag A 1998 Modulation of mouse estrogen receptor transcription activity by protein kinase $\mathrm{C}$ delta. Journal of Molecular Endocrinology 20 245-259.

Larsen SS, Madsen MW, Jensen BL \& Lykkesfeldt AE 1997 Resistance of human breast-cancer cells to the pure steroidal anti-estrogen ICI 182,780 is not associated with a general loss of estrogen-receptor expression or lack of estrogen responsiveness. International Journal of Cancer 72 11291136.

Lawrence DS \& Niu J 1998 Protein kinase inhibitors: the tyrosine-specific protein kinases. Pharmacology and Therapeutics 77 81-114.

Lee AV, Weng CN, Jackson JG \& Yee D 1997 Activation of estrogen receptor-mediated gene transcription by IGF-I in human breast cancer cells. Journal of Endocrinology 152 3947.

Lee DK, Kim B, Lee SG, Gwon HJ, Moon EY, Hwang HS, Seong SK, Lee M, Lim MJ, Sung HJ, Shin DH, Yoon SJ \& Yang CH 1998 Momordins inhibit AP-1 function and cell proliferation. Anticancer Research 18 119-124.

Le Goff P, Montano MM, Schodin DJ \& Katzenellenbogen BS 1994 Phosphorylation of the human estrogen receptor. Identification of hormone-regulated sites and examination of their influence on transcriptional activity. Journal of Biological Chemistry 269 4458-4466.

Lehrer S, O'Shaughnessy J, Song HK, Levine E, Savoretti P, Dalton J, Lipsztein R, Kalnicki S \& Bloomer WD 1989 Activity of pp60c-src protein kinase in human breast cancer. Mount Sinai Journal of Medicine 56 83-85.

Levitzki A 1996 SRC as a target for anti-cancer drugs. Anti Cancer Drug Design 11 175-182.

Linardopoulos S, Malliri A, Pintzas A, Vassilaros S, Tsikkinis A \& Spandidos DA 1990 Elevated expression of AP-1 activity in human breast tumors as compared with normal adjacent tissue. Anticancer Research 10 1711-1713.

Lukas J, Bartkova J \& Bartek J 1996 Convergence of mitogenic signalling cascades from diverse classes of receptors at the cyclin D-cyclin-dependent kinase-pRb-controlled G1 checkpoint. Molecular and Cellular Biology 16 6917-6925.

Lundy J, Schuss A, Stanick D, McCormack ES, Kramer S \& Sorvillo JM 1991 Expression of neu protein, EGFR, and transforming growth factor alpha in breast cancer: Correlation with clinicopathological parameters. American Journal of Pathology 138 1527-1534.

McClelland RA, Manning DL, Gee JM, Anderson E, Clarke R, Howell A, Dowsett M, Robertson JF, Blamey RW, Wakeling AE \& Nicholson RI 1996 Effects of short-term antiestrogen treatment of primary breast cancer on estrogen receptor mRNA and protein expression and on estrogen-regulated genes. Breast Cancer Research and Treatment 41 31-41.

McDonnell DP, Dana SL, Hoener PA, Lieberman BA, Imhof MO \& Stein RB 1995 Cellular mechanisms which distinguish between hormone- and antihormone-activated estrogen receptor. Annals of the New York Academy of Sciences $\mathbf{7 6 1}$ 121-137.

McGraw K, McKay R, Miraglia L, Boggs RT, Pribble JP, Muller M, Geiger T, Fabbro D \& Dean NM 1997 Antisense oligonucleotide inhibitors of isozymes of protein kinase C: in vitro and in vivo activity, and clinical development as anticancer therapeutics. Anti Cancer Drug Design 12 315-326.

Mangiarotti R, Danova M, Alberici R \& Pellicciari C 1998 Alltrans retinoic acid (ATRA)-induced apoptosis is preceded by G1 arrest in human MCF-7 breast cancer cells. British Journal of Cancer 77 186-191.

Matsuda S, Kadowaki Y, Ichino M, Akiyama T, Toyoshima K \& Yamamoto T 199317 beta-estradiol mimics ligand activity of the c-erbB2 protooncogene product. Proceedings of the National Academy of Sciences of the USA 90 10803-10807.

Matsui Y, Halter SA, Holt JT, Hogan BL \& Coffey RJ 1990 Development of mammary hyperplasia and neoplasia in MMTV-TGF alpha transgenic mice. Cell 61 1147-1155.

Melner MH 1996 Physiological inhibitors of protein kinase C. Biochemical Pharmacology 51 869-877.

Migliaccio A, Pagano M \& Auricchio F 1993 Immediate and transient stimulation of protein tyrosine phosphorylation by estradiol in MCF-7 cells. Oncogene 8 2183-2191.

Minden A, Lin A, Smeal T, Derijard B, Cobb M, Davis R \& Karin M 1994 c-Jun N-terminal phosphorylation correlates with activation of the JNK subgroup but not the ERK subgroup of mitogen-activated protein kinases. Molecular and Cellular Biology 14 6683-6688.

Mohamood AS, Gyles P, Balan KV, Hollis VW, Eckberg WR, Asseffa A, Han Z, Wyche JH \& Anderson WA 1997 Estrogen receptor, growth factor receptor and protooncogene protein activities and possible signal transduction crosstalk in estrogen dependent and independent breast cancer cell lines. Journal of Submicroscopic Cytology and Pathology 29 1-17.

Monia BP, Johnston JF, Ecker DJ, Zounes MA, Lima WF \& Freier SM 1992 Selective inhibition of mutant Ha-ras mRNA expression by antisense oligonucleotides. Journal of Biological Chemistry 267 19954-19962.

Monia BP, Johnston JF, Geiger T, Muller M \& Fabbro D 1996 Antitumor activity of a phosphorothioate antisense oligodeoxynucleotide targeted against C-raf kinase. Nature Medicine 2 668-675. 
Morishita S, Niwa K, Ichigo S, Hori M, Murase T, Fujimoto J \& Tamaya T 1995 Overexpressions of $\mathrm{c}$-fos/jun mRNA and their oncoproteins (Fos/Jun) in the mouse uterus treated with three natural estrogens. Cancer Letters 97 225-231.

Musgrove EA, Hamilton JA, Lee CS, Sweeney KJ, Watts CK \& Sutherland RL 1993 Growth factor, steroid, and steroid antagonist regulation of cyclin gene expression associated with changes in T-47D human breast cancer cell cycle progression. Molecular and Cellular Biology 13 3577-3587.

Nagpal S, Athanikar J \& Chandraratna RA 1995 Separation of transactivation and AP1 antagonism functions of retinoic acid receptor alpha. Journal of Biological Chemistry 270 923-927.

Newmark HL 1997 Squalene, olive oil, and cancer risk: a review and hypothesis. Cancer Epidemiology Biomarkers and Prevention 6 1101-1103.

Nicholson RC, Mader S, Nagpal S, Leid M, Rochette-Egly C \& Chambon P 1990 Negative regulation of the rat stromelysin gene promoter by retinoic acid is mediated by an AP1 binding site. EMBO Journal 9 4443-4454.

Nicholson RI \& Gee JWM 1996 Growth factors and modulation of endocrine response in breast cancer. In Hormones and Cancer, pp 227-261. Ed WV Vedeckis. Boston: Birkhauser.

Nicholson RI, McClelland RA, Finlay P, Eaton CL, Gullick WJ, Dixon AR, Robertson JFR, Ellis IO \& Blamey RW 1993 Relationship between EGF-R, c-erbB-2 protein expression and Ki67 immunostaining in breast cancer and hormone sensitivity. European Journal of Cancer 29A 1018-1023.

Nicholson RI, McClelland RA, Gee JM, Manning DL, Cannon P, Robertson JF, Ellis IO \& Blamey RW 1994a Transforming growth factor-alpha and endocrine sensitivity in breast cancer. Cancer Research 54 1684-1689.

Nicholson RI, McClelland RA, Gee JMW, Manning DL, Cannon P, Robertson JFR, Ellis IO \& Blamey RW 1994b Epidermal growth factor receptor expression in breast cancer: association with response to endocrine therapy. Breast Cancer Research and Treatment 29 117-125.

Nicholson RI, Gee JWM, Manning DL, Wakeling AE \& Katzenellenbogen BS $1995 a$ Responses to pure antioestrogens (ICI 164384 and ICI 182780) in oestrogen sensitive and resistant experimental and clinical breast cancer. Annals of the New York Academy of Sciences 761 148-163.

Nicholson RI, Gee JMW, Francis AB, Manning DL, Wakeling AE \& Katzenellenbogen BS $1995 b$ Observations arising from the use of pure antioestrogens on oestrogen-responsive (MCF7) and oestrogen growth-independent (K3) human breast cancer cells. Endocrine-Related Cancer 2 115-121.

Nicholson RI, Gee JMW, Jones H, Harper ME, Wakeling AE, Willsher P \& Robertson JFR 1997 erbB Signalling and endocrine sensitivity of human breast cancer. In $E G F$ Receptor in Tumour Growth and Progression, pp 105-128. Eds RB Lichtner \& RN Harkins. Boston: Springer-Verlag.

Nicholson S, Halcrow P, Fardon JR, Sainsbury JRC, Chambers P \& Harris AL 1989 Expression of epidermal growth factor receptors associated with lack of response to endocrine therapy in recurrent breast cancer. Lancet i 182-185.

Olive M, Krylov D, Echlin DR, Gardner K, Taparowsky E \& Vinson C 1997 A dominant negative to activation protein-1
(AP1) that abolishes DNA binding and inhibits oncogenesis. Journal of Biological Chemistry 272 18586-18594.

Onoda T, Iinuma H, Sasaki Y, Hamada M, Isshiki K, Naganawa H, Takeuchi T, Tatsuta K \& Umezawa K 1989 Isolation of a novel tyrosine kinase inhibitor, lavendustin A, from Streptomyces griseolavendus. Journal of Natural Products 52 1252-1257.

Osborne CK \& Coronado-Heinsohn E 1996 Targeting the epidermal growth factor receptor in breast cancer cell lines with a recombinant ligand fusion toxin. Cancer Journal from Scientific American 2175.

Pendurthi UR, Williams JT \& Rao LV 1997 Inhibition of tissue factor gene activation in cultured endothelial cells by curcumin. Suppression of activation of transcription factors Egr-1, AP-1, and NF-kappa B. Arteriosclerosis, Thrombosis and Vascular Biology 17 3406-3413.

Pfahl M 1993 Nuclear receptor/AP-1 interaction. Endocrine Reviews 14 651-658.

Philip PA \& Harris AL 1995 Potential for protein kinase C inhibitors in cancer therapy. Cancer Treatment and Research 78 3-27.

Philips A, Chalbos D \& Rochefort H 1993 Estradiol increases and anti-estrogens antagonize the growth factor-induced activator protein-1 activity in MCF7 breast cancer cells without affecting c-fos and c-jun synthesis. Journal of Biological Chemistry 268 14103-14108.

Pietras RJ, Arboleda J, Reese DM, Wongvipat N, Pegram MD, Ramos L, Gorman CM, Parker MG, Sliwkowski MX \& Slamon DJ 1995 HER-2 tyrosine kinase pathway targets estrogen receptor and promotes hormone-independent growth in human breast cancer cells. Oncogene 10 2435-2446.

Pratt WB \& Toft DO 1997 Steroid receptor interactions with heat shock protein and immunophilin chaperones. Endocrine Reviews 18 306-360.

Reuveni H, Gitler A, Poradosu E, Gilon C \& Levitzki A 1997 Synthesis and biological activity of semipeptoid farnesyltransferase inhibitors. Bioorganic and Medicinal Chemistry 5 85-92.

Rochefort H 1995 Oestrogen- and anti-oestrogen-regulated genes in human breast cancer. Ciba Foundation Symposium 191 254-265.

Salomon DS, Kim N, Saeki T \& Ciardiello F 1990 Transforming growth factor-alpha: an oncodevelopmental growth factor. Cancer Cells 2 389-397.

Sandgren EP, Luetteke NC, Palmiter RD, Brinster RL \& Lee DC 1990 Overexpression of TGF alpha in transgenic mice: induction of epithelial hyperplasia, pancreatic metaplasia, and carcinoma of the breast. Cell 61 1121-1135.

Scherr M, Grez M, Ganser A \& Engels JW 1997 Specific hammerhead ribozyme-mediated cleavage of mutant N-ras mRNA in vitro and ex vivo. Oligoribonucleotides as therapeutic agents. Journal of Biological Chemistry 272 14304-14313.

Segnitz B \& Gehring U 1995 Subunit structure of the nonactivated human estrogen receptor. Proceedings of the National Academy of Sciences of the USA 92 2179-2183. 
Shiu RP, Watson PH \& Dubik D 1993 c-myc oncogene expression in estrogen-dependent and -independent breast cancer. Clinical Chemistry 39 353-355.

Siegall CB, Bacus SS, Cohen BD, Plowman GD, Mixan B, Chace D, Chin DM, Goetze A, Green JM \& Hellstrom I 1995 HER4 expression correlates with cytotoxicity directed by a heregulin-toxin fusion protein. Journal of Biological Chemistry 270 7625-7630.

Singh SV, Mohan RR, Agarwal R, Benson PJ, Hu X, Rudy MA, Xia H, Katoh A, Srivastava SK, Mukhtar H, Gupta V \& Zaren HA 1996 Novel anti-carcinogenic activity of an organosulfide from garlic: inhibition of H-RAS oncogene transformed tumor growth in vivo by diallyl disulfide is associated with inhibition of p21H-ras processing. Biochemical and Biophysical Research Communications 225 660-665.

Sivaraman VS, Wang H, Nuovo GJ \& Malbon CC 1997 Hyperexpression of mitogen-activated protein kinase in human breast cancer. Journal of Clinical Investigation 99 1478-1483.

Smith CL, Conneely OM \& O’Malley BW 1993 Modulation of the ligand-independent activation of the human estrogen receptor by hormone and antihormone. Proceedings of the National Academy of Sciences of the USA 90 6120-6124.

Tang P, Hung MC \& Klostergaard J 1994 TNF cytotoxicity: effects of HER-2/neu expression and inhibitors of ADPribosylation. Lymphokine and Cytokine Research 13 117-123.

Tiniakos DG, Scott LE, Corbett IP, Piggott NH \& Horne CH 1994 Studies of c-jun oncogene expression in human breast using a new monoclonal antibody, NCL-DK4. Journal of Pathology 172 19-26.

Toi M, Mukaida H, Wada T, Hirabayashi N, Toge T, Hori T \& Umezawa K 1990 Antineoplastic effect of erbstatin on human mammary and esophageal tumors in athymic nude mice. European Journal of Cancer 26 722-724.

Trowbridge JM, Rogatsky I \& Garabedian MJ 1997 Regulation of estrogen receptor transcriptional enhancement by the cyclin A/Cdk2 complex. Proceedings of the National Academy of Sciences of the USA 94 10132-10137.

Tzeng DZ \& Klinge CM 1996 Phosphorylation of purified estradiol-liganded estrogen receptor by casein kinase II increases estrogen response element binding but does not alter ligand stability. Biochemical and Biophysical Research Communications 223 554-560.

Umekita Y, Enokizono N, Sagara Y, Kuriwaki K, Takasaki T, Yoshida A \& Yoshida H 1992 Immunohistochemical studies on oncogene products (EGF-R, c-erbB-2) and growth factors (EGF, TGF-alpha) in human breast cancer: their relationship to oestrogen receptor status, histological grade, mitotic index and nodal status. Virchows Archiv A - Pathological Anatomy and Histopathology 420 345-351.
Umezawa K 1995 Isolation and biological activities of signal transduction inhibitors from microorganisms and plants. Advances in Enzyme Regulation 35 43-53.

Umezawa K, Ohse T, Yamamoto T, Koyano T \& Takahashi Y 1994 Isolation of a new vinca alkaloid from the leaves of Ervatamia microphylla as an inhibitor of ras functions. Anticancer Research 14 2413-2417.

Wakeling AE, Barker AJ, Davies DH, Brown DS, Green LR, Cartlidge SA \& Woodburn JR 1996 Specific inhibition of epidermal growth factor receptor tyrosine kinase by 4anilinoquinazolines. Breast Cancer Research and Treatment 38 67-73.

Wakeling AE, Barker AJ, Davies DH, Brown DS, Green LR, Cartlidge SA \& Woodburn JR 1997 New targets for therapeutic attack. Endocrine-Related Cancer 4 351-355.

Walker KJ, Price-Thomas JM, Candlish W \& Nicholson RI 1991 Influence of the antioestrogen tamoxifen on normal breast tissue. British Journal of Cancer 64 764-768.

Walker KJ, McClelland RA, Candlish W, Blamey RW \& Nicholson RI 1992 Heterogeneity of oestrogen receptor expression in normal and malignant breast tissue. European Journal of Cancer 28 34-37.

Wang C, Thor AD, Moore DH II, Zhao Y, Kerschmann R, Stern R, Watson PH \& Turley EA 1998 The overexpression of RHAMM, a hyaluronan-binding protein that regulates ras signaling, correlates with overexpression of mitogenactivated protein kinase and is a significant parameter in breast cancer progression. Clinical Cancer Research 4 567576.

Ward WHJ, Cook, PN, Slater AM, Davies DH, Holdgate GA \& Green LR 1994 Epidermal growth factor receptor tyrosine kinase. Investigation of catalytic mechanism, structure-based searching and discovery of a potent inhibitor. Biochemical Pharmacology 48 659-666.

Webb P, Lopez GN, Uht RM \& Kushner PJ 1995 Tamoxifen activation of the estrogen receptor/AP-1 pathway: potential origin for the cell-specific estrogen-like effects of antiestrogens. Molecular Endocrinology 9 443-456.

Wiechen K \& Dietel M 1995 c-erbB-2 anti-sense phosphorothioate oligodeoxynucleotides inhibit growth and serum-induced cell spreading of P185c-erbB-2overexpressing ovarian carcinoma cells. International Journal of Cancer 63 604-608.

White R \& Parker MG 1998 Molecular mechanisms of steroid hormone action. Endocrine-Related Cancer 5 1-14.

Xu YX, Pindolia KR, Janakiraman N, Chapman RA \& Gautam SC 1997 Curcumin inhibits IL1 alpha and NF-alpha induction of AP-1 and NF-kB DNA-binding activity in bone marrow stromal cells. Hematopathology and Molecular Hematology 11 49-62. 